\title{
Challenges and Countermeasures of College English Teaching from the Perspective of Curriculum Theory
}

\author{
Lv Yixian, Kou Junjia \\ Jiangxi Teachers College, Yingtan, Jiangxi, 335000, China
}

\begin{abstract}
Keywords: Curriculum theory; college English teaching
\end{abstract}
\begin{abstract}
This study draws lessons from the modern teaching idea in the view of new curriculum, and it analyzes the current situation of college students' learning and the present situation of English teachers' teaching. It puts forward some suggestions on these problems. This study pays attention to practice theory, and serves the practice of teaching. Based on the in-depth investigation of college students, the paper analyzes the current situation of English curriculum resources and teaching. So teachers can understand the characteristics of college students' thinking mode and understand the weakness of college students studying English. Teachers develop English curriculum resources under the guidance of new curriculum theory. The research conclusion has the guiding value to the university English teaching practice.
\end{abstract}

\section{Introduction}

With the social and economic globalization and life information, as an important information carrier, English gradually becomes an indispensable communication tool in life, work areas. Accordingly, China Education Ministry stipulates that universities must set up public compulsory courses, which is College English. English becomes a compulsory course for college students [1-3]. In the university campus, we often see students carrying on daily dialogue and exchange with English. In many corners of the street, you may also meet foreigners who speak English at any time, and they sometimes need you to help them in English (such as directions, shopping and local attractions). Therefore, English has become the basis and prerequisite for our communication with foreigners. Different specific curriculum forms imply different ways of thinking. It directly or indirectly affects the researcher's thinking and answers to those important substantive course questions. The new curriculum system has a major innovation and breakthrough in the course of the original in such aspects as function, content, goal of the course $[4,5]$. The new curriculum view is based on the elimination of the shortcomings of the traditional curriculum demands. It cultivates students' innovative spirit and practical ability of practical needs. The new curriculum concept not only changes the teacher's educational concept, but also changes their daily practice and teaching methods and teaching behavior. In practice, some humanists advocate a confluent curriculum, which emphasizes the integration of emotion and cognition [6]. That is to give the course content to personal significance by adding emotional factors to the regular course.

This paper analyses students learning English weaknesses, shortcomings with the college English curriculum and teaching implementation. Interviews and their own teaching experience are as specific research methods. It puts forward targeted recommendations, and contributes to higher English level graduates. 


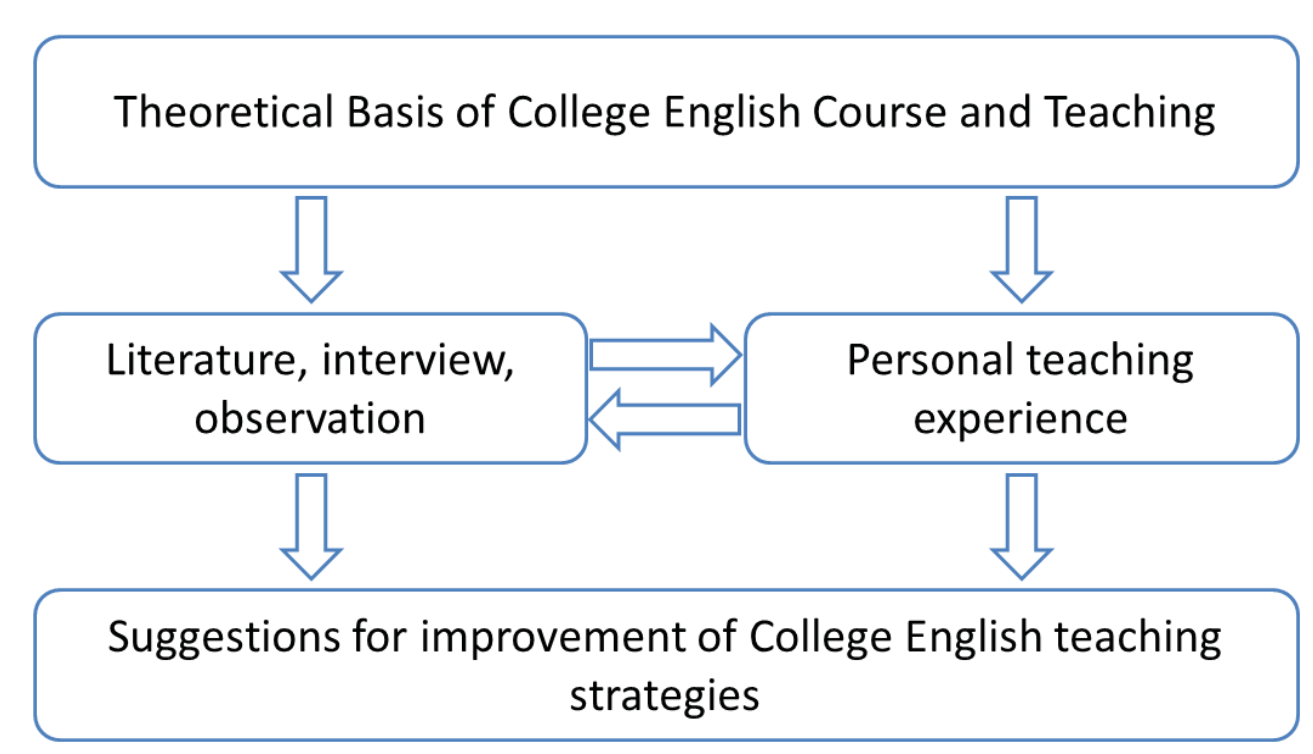

Fig.1. The research idea

\section{Modern English teaching philosophy from the perspective of new curriculum}

The teaching process is the process of teacher-student communication, active mutual assistance and common development. The goal of English teaching is to cultivate the comprehensive application ability of students, especially listening and speaking ability. So that they can be effective oral and written information exchange with English in the future work and social interaction. While enhancing their self-learning ability to, it improves the comprehensive cultural quality to adapt to China's economic development and international exchange [7, 8]. Modern English teaching is a complex art. In teaching, it is important not to impart English knowledge to students, but to guide students to master learning methods on the basis of English learning. The dependence on teachers of modern students is not as high as before. Autonomy and creative learning are the habit that students should gradually develop.

Therefore, in modern English teaching, teachers should change their traditional ideas, such as anchor teaching, exemplary teaching, discovery law teaching and discussion law teaching and so on. This teaching is conducive to future learning and development of students. It is concluded that modern English teaching is centered on students. The teaching process focuses on cultivating students' ability to think independently, analyze problems and solve problems. Pay attention to direct participation, practice and extracurricular learning of students, especially lectures or presentations. Therefore, modern English teaching should give full play to the main role of students. Mobilize the enthusiasm of students because they are the center of cooperative learning. Put emotion, and respect individual differences in students. Improve the quality of teachers themselves, overcome the traditional education model, unity and cooperation, share teaching skills, and cope with modern English teaching.

\section{The Present Situation of College English Teaching}

\subsection{The Current Situation of English Learning for Students}

The teaching model of college English curriculum in the network environment is a new perspective of the teaching reform of higher education in our country. The teaching design transforms from knowledge as the center to resource and student as the center. Students become the subject of learning in this study. The development of students is the ultimate goal of college English teaching under the new curriculum view. The ability of students to use English is the embodiment of English teaching. 10 closed questions and 1 open question are designed for the views of students on English learning (see in Table 1). 
Table 1. Questionnaire of English teaching under the new curriculum view way 1. What do you think a good English teaching model is?
A. based on teacher 's teaching
B. based on students' discussing

C. based on interaction between teachers and

D. others students

2. What do you think of your English classroom atmosphere?

\begin{tabular}{|l|l|l}
\hline A. serious & B. loose & C. more loose
\end{tabular}

3. Can you follow the teaching rhythm of teachers?

\begin{tabular}{|l|l|l|}
\hline A. can & B can generally & C. can not
\end{tabular}

4. How much time do you use to learn English every week?

\begin{tabular}{|l|l|}
\hline A. 30 hours and above & B. $10-30$ hours \\
\hline C. $5-10$ hours & D. rarely spend time learning English \\
\hline
\end{tabular}

5. How many semesters should be more suitable for college English?

\begin{tabular}{|l|l|l|l|}
\hline A. four & B. five & C. six & D. seven \\
\hline 6
\end{tabular}

6. Do you find a teacher tutoring English after school?

\begin{tabular}{|l|l|l|}
\hline A. no & B. occasional & C. often \\
\hline
\end{tabular}

7. What do you think the focus of learning English is?

\begin{tabular}{l|l|l}
\hline A. Vocabulary & B. Grammar & C. Listening and Reading \\
\hline
\end{tabular}

8. What do you think the biggest difficulty in English learning is?

\begin{tabular}{|l|l|l|l|}
\hline A. Listening & B. Vocabulary & C. Grammar & D. Reading and Translating \\
\hline
\end{tabular}

9. What do you think the key to learning English is?
A. self-learning method and the effort
B. teaching method
C. Textbook content
D. others

10. What level do you think you can pass English before you graduate?

\begin{tabular}{l|l|l|l|}
\hline A. Level 4 & B. Level 6 & C. Level 3 & D. no one \\
\hline $\begin{array}{l}\text { 11. Talk about your overall view of English learning, as well as the teacher's } \\
\text { teaching methods have any suggestions and what is your suggestion to teaching } \\
\text { methods? }\end{array}$
\end{tabular}

The student questionnaire is shown in Table 2. The survey results show that students' interest in learning English, the situation and the view of English learning. 
Table 2. Questionnaire statistics of the 2010 class college students

\begin{tabular}{|c|c|c|c|c|}
\hline Question number & $\mathrm{A} \mathrm{( \% )}$ & $\mathrm{B} \mathrm{( \% )}$ & $\mathrm{C} \mathrm{( \% )}$ & $\mathrm{D} \mathrm{( \% )}$ \\
\hline 1 & 32 & 18 & 30 & 20 \\
\hline 2 & 34 & 49 & 17 & $/$ \\
\hline 3 & 20.5 & 27 & 52.5 & $/$ \\
\hline 4 & 49 & 21 & 20 & 10 \\
\hline 5 & 36.5 & 37 & 27 & 9.5 \\
\hline 6 & 58 & 30 & 12 & $/$ \\
\hline 7 & 48.6 & 31.2 & 11.2 & $/$ \\
\hline 8 & 52.4 & 10.3 & 13.3 & 14 \\
\hline 9 & 60 & 13 & 20 & 7 \\
\hline 10 & 10 & 3 & 82 & 5 \\
\hline
\end{tabular}

\subsection{The Present Situation of the Implementation of College English Teaching}

Qualified English teachers who have the professional quality should have a more solid professional knowledge, teaching organization ability, teaching implementation ability, high character cultivation, pleasant personal character, more systematic modern language knowledge, quite English acquisition of theoretical knowledge and a certain knowledge of English teaching methods and so on. The teachers who were surveyed have reached the requirements of college English teachers. Because now the threshold of entering the university is getting higher and higher, so teachers are engaged in English teaching are basically graduate students. The character cultivation of teachers is higher, needless to say academic ability. Scientific research and teaching ability are required to conduct a rigorous assessment before entering the university. According to the interview with the students, more than $85 \%$ of the students are very familiar with the English level of teacher. They are the model and guide people of students.

\section{Strategies to improve college English teaching}

\subsection{Choose suitable English teaching materials for college students}

The teaching material serves for the purpose of teaching. Teaching materials are important sources of teaching and learning and curriculum resources. The method of teaching and learning depends on the content of the textbook to a certain extent. The teaching materials should provide the best language samples for the classroom teaching and the material of the systematic language practice. University leaders and teachers should strengthen contact and communication. They should seriously carry out research, so as to select the unified college English textbooks. They should not adopt "closed" type teaching. But the English level of students is uneven. After dividing into two or three levels, you can choose suitable English textbooks for each level. For example, for students with a high level of English, you should choose textbooks that focus on grammar, basic vocabulary and simple listening. Fof the sophomore and above college students, you can choose textbooks which focus on reading comprehension, listening, speaking and writing skills. This is the only way to meet the principle of teaching students in accordance with their aptitude.

\subsection{Cultivate the listening and speaking skills of students}

First of all, teachers should establish a humorous teaching concept. In the eyes of ordinary students, the teachers are very sacred and serious. Some students in the classroom have nervous psychology, so the English teacher can break the traditional, humorous way of teaching. Foreign education experts believe that humorous can cultivate the creativity and optimism. Classroom humor is the perfect combination of knowledge, students and personal teaching charm of teachers. A loving English teacher using humorous teaching methods can make the classroom more harmonious in the classroom. Students will listen carefully, understand the knowledge easily in relaxed classroom. 


\section{Summary}

The curriculum is also constantly updated with the development of times. Modern college English teaching will become more dynamic in the new curriculum perspective. Because students have English foundation, learning environment, interest in English and so on factors, the college English teaching for teachers is a very big challenge. It is very fortunate that I was engaged in this study and at the same time engaged in college English teaching, which gave me the practice and research soil. Because of the limitation of the language, the knowledge, and the complexity of the subject and so on, the research done in this paper is more superficial.

\section{References}

[1] On B. A Review and Prospect of College English Teaching Research under the Perspective of Curriculum Theory: [J]. Computer-Assisted Foreign Language Education, 2013.

[2] Chen J, Ruijuan Y E, Sun Yat-sen University. The Construction of College English Curriculum in Light of the CBI Theory [J]. Journal of Yangzhou University, 2013.

[3] Qian G, Wang M, Wei J, et al. On the Curriculum Setting Management of College English ESP Elective Courses Based on Demand Theory[C]// International Conference on Economics and Management Innovations. 2016.

[4] Niu D Y. An ESP Theory-based College English Curriculum System Exploration about Higher Vocational Institutions [J]. Journal of Southern Vocational Education, 2012.

[5] Wang Y A, Wang Y. A Study on the Action Research of College English Listening Curriculum Reform from the Perspective of Circulation Theory [J]. Foreign Language Learning Theory \& Practice, 2013.

[6] Shi H M. Application of interpretation theory in college English fundamental curriculum teaching [J]. Journal of Jiamusi Education Institute, 2012.

[7] Xing X. Exploration on Curriculum Construction of College English Based on the Theory of Autonomous Learning [J]. Read \& Write Periodical, 2012.

[8] Jun M O. A Study on College Tourism English Curriculum Reform Guided by Systematic Working Process Theory [J]. Journal of Anhui Vocational \& Technical College, 2013. 